\title{
Market Funds and Trust-Investment Law: II
}

\author{
John H. Langbein and Richard A. Posner
}

In an article published last year in this journal, we invited attention to the legal implications of the rise of the market-fund concept. ${ }^{1}$ This concept-a radical departure from conventional investment ideasteaches that institutional investors who try to "beat the market" by buying stocks they believe to be undervalued and selling those they believe to be overvalued are likely to do worse in the long run than investors who adopt the passive strategy of buying and holding a portfolio of stocks designed to approximate the stock market as a whole. We argued that the decision of a trustee to invest trust assets in a mutual fund or equivalent vehicle employing the passive strategy-a "market fund"-raised only superficial problems of conformity with the law governing investments by trustees, that "market matching" was the superior strategy for a trustee to adopt, and that the courts would come around to this view.

Our article created both interest and controversy in the investment community. ${ }^{2}$ We were invited to address a number of conferences and

John H. Langbein and Richard A. Posner are Professors of Law at the University of Chicago and Affiliated Scholars at the American Bar Foundation.

The authors wish to thank Fischer Black, John Bogle, Walter Blum, Kenneth Dam, Lewis Dembitz, Allison Dunham, Richard Epstein, William Fouse, Bernard Meltzer, Roger Murray, Myron Scholes, Evan Schulman, Rex Sinquefield, Jan Twardowski, and Lawrence Waggoner for their helpful comments on previous drafts of this article, and the American Bar Foundation for its financial assistance. The views expressed are those of the authors, not of the Foundation.

1. John H. Langbein \& Richard A. Posner, Market Funds and Trust-Investment Law, 1976 A.B.F. Res. J. 1 [hereinafter cited as Market Funds I]. For a simplified treatment see John $\mathrm{H}$. Langbein \& Richard A. Posner, The Revolution in Trust Investment Law, 62 A.B.A.J. 887 (1976).

2. See, e.g., Paul R. Merrion, Study Claims Market Funds Are Prudent, Pensions \& Investments, Jan. 19, 1976, at 3; Index Fund Study Provides Needed Perspective, Pensions \& Investments, Feb. 2, 1976, at 8; Nancy Belliveau, Will Pension Officers Stop Trying to Beat the Market? Institutional Investor, Feb. 1976, at 18; Robert Metz, Debate over "Market Index" Funds, N.Y. Times, Jan. 21, 1976, at 52, col. 3; "Vanity, All Is Vanity," Forbes, Dec. 15, 1975, at 66 . 
seminars sponsored by brokerage houses and other investment institutions, and there we encountered a good deal of hostility ${ }^{3}$-along with a surprising amount of support. The hostility of the investment community to our approach was predictable, since the strategy of buying and holding a market-matching portfolio reduces both brokerage commissions and the role of the security analyst in the investment process. In responding to questions and comments raised by friendly and unfriendly critics, our own ideas concerning market funds and trust-investment law were tested, refined, and on the whole confirmed.

The present article amplifies and extends the analysis in the previous article. In Part I we recapitulate very briefly the essential points made in that article, but this part should not be considered a substitute for it. In Part II we reply to the objections that have been made to our analysis. In Part III we discuss some limitations of the market-fund concept that we acknowledge as a guide to investment by trustees; in Part IV, the implications of our analysis for the duty to diversify conventionally managed trust investments. In Part $\mathrm{V}$ we consider an important regulatory question presented by the market-fund concept: whether banks should be permitted to offer market funds unconnected with their trust services.

\section{RECAPITULATION}

\section{A. Capital-Market Theory}

A large and growing body of empirical evidence, summarized in our previous article, demonstrates that conventional investment principles, as reflected in the performance of mutual funds and other institutional investors, have produced consistently disappointing results. Not only have institutional portfolios managed in accordance with the conventional principles of investment failed to outperform, in terms of

3. One snowy morning last January, a law professor named Richard Posner gave a talk at a conference on pension-fund investing at New York's Plaza Hotel. Posner was far and away the least popular speaker at the conference. As the drift of his message began to get across to the audience, an angry buzz filled the Terrace Room; before he had finished speaking, many in the audience were no longer listening, but denouncing him to others at their tables. Subsequent speakers warmed themselves to the group by starting off with slighting references to Posner's remarks.

The reason for this ill will was all too clear. The audience consisted mainly of professional money managers, most of whom pride themselves on their ability to offer superior investment performance. Posner's message was that they are wasting their time. It is impossible to beat the market averages, he insisted, and efforts to do so are expensive and self-defeating. The managers would do better; Posner argued, by investing their customers' assets in "index funds"-portfolios that duplicate broad stock-market averages like the Standard \& Poor's 500.

A. F. Ehrbar, Index Funds-An Idea Whose Time Is Coming, Fortune, June 1976, at 145. 
risk-adjusted return, ${ }^{4}$ the broad stock market averages, such as Standard and Poor's 500 (S\&P 500); when their management fees and other administrative expenses are taken into account, the conventionally managed portfolios can be shown to have underperformed the market averages. Exceptions to this pattern appear to be exceedingly rare. ${ }^{5}$

The evidence thus shows the stock market to be "efficient," in the special sense that, at existing levels of securities research and analysis, the gains from additional searching for bargains in securities appear to be negative, at least for the institutional investor. The institutional investor that stopped trying to beat the market could expect a higher net return because of the reduction in research and transaction costs. ${ }^{6}$

The implications of capital-market theory are not wholly negative. The theory also suggests an efficient investment strategy. The essence of this strategy is to buy and hold a very broadly diversified portfolioideally, one in which all securities would be held in proportion to the market value of the companies issuing them. Diversification reduces portfolio risk: the portfolio that contains two airline stocks instead of one is protected against the risk that one will be struck; the portfolio that contains oil as well as airline stocks is protected (in part anyway) against the risk to the airline industry of a sharp increase in the price of aviation fuel. Although the reduction in risk brought about by diversification would have no value to investors who were indifferent to risk (and would have a negative value to gamblers), studies have shown that most investors are averse to risk; and this aversion must be even more prevalent among trust beneficiaries as a class than among investors generally.

Even a maximally diversified common stock portfolio would not be completely free from risk. The market as a whole fluctuates from day to day and month to month, often quite dramatically, and these

4. The importance of this qualification is stressed in text at notes 35-36 infra.

5. See text at notes 39-40 infra.

6. If all investors stopped trying to beat the market, there would be net gains from research and trading. This possibility is considered in Part IIA infra. Beyond the reasons presented in our previous article why it is so difficult to beat the market, we note a special disadvantage of the large institutional investor: its efforts to exploit undiscounted information by buying or selling a security are apt to be thwarted by the price effect of its transaction due to the large volume in which it buys or sells. The large order signals the possible possession of information and so may cause the price to the institution placing the order to rise (if a buy order) or fall (if a sell order). Further, the sheer size of many institutional portfolios makes it difficult for the institution to act on undiscounted information. Supposing that an institution decides that one of its large holdings is overvalued, sales will have to be spread over a long period to avoid a dumping effect that would depress the market. Likewise, the institution that thinks it has spotted a bargain (i.e., an undervalued stock) would need to spread out its purchases lest it bid up the price and eliminate the bargain, but as the acquisition period lengthens so does the probability that other investors will identify the bargain. 
fluctuations are a source of risk (one might have to liquidate one's stock investments at a time when the market was down). Fortunately, this risk-the unavoidable risk of equity ownership-is compensated: the expected return of equity securities has exceeded, at least on a longterm basis, $^{7}$ that of debt securities of the same companies precisely because the equity return (appreciation plus dividends) is more volatile than the return on fixed-income securities.

The risk of a security has two components: (1) diversifiable risk, which can be eliminated by holding a diversified portfolio, and (2) systematic risk, or beta, the risk that is shared with equity securities as a whole. The greater the systematic risk of a security-the higher the beta, in other words-the greater the expected return of the stock, for investors demand compensation for bearing risk that cannot be eliminated by diversification. ${ }^{8}$ Given the positive correlation between systematic risk and expected return, it follows that the portfolio manager can, within certain limits, alter the expected return of the portfolio by changing the beta of the portfolio. If he is willing to bear increased risk, he can increase his expected return without doing any stock picking. But he cannot increase his expected return simply by reducing the diversification of the portfolio. Diversifiable risk is uncompensated risk; no one will pay an investor for the investor's failure to diversify.

From this analysis, the market or index fund emerges as a highly attractive investment vehicle, at least for the risk-averse investor (a class to which, we repeat, most trust beneficiaries belong). The market fund holds a broadly diversified portfolio, engages in no research, and trades only to the extent necessary to maintain the desired level of diversification, handle redemptions, and so forth. The market-fund portfolio contains hundreds of stocks, because, as explained in our previous article, small but nonnegligible reductions in diversifiable risk can be achieved at very low cost (in a multimillion-dollar portfolio) by substantially increasing the number of stocks held in conventionally managed institutional portfolios. ${ }^{9}$

7. We add this qualification to abstract from the (one hopes temporary) problem of rapid changes in the rate of inflation. A fixed-income security involves a risk-that the anticipated rate of inflation will change before the security matures-which common stocks do not involve, at least to the same extent. This risk could cause investors to demand a premium for purchasing fixed-income securities that could conceivably exceed the risk premium of common stocks, leading bonds to command a higher return than common stocks.

8. The New York Stock Exchange (NYSE) list (weighted by the capital values of the listed companies) has a beta of 1 ; a portfolio having a beta of 2 would rise by 20 percent if the NYSE list rose by 10 percent, and decline by 20 percent if the NYSE list fell by 20 percent, assuming that factors affecting the diversifiable risk of the portfolio in question were unchanged.

9. Capital-market research has not specified a precise number of stocks as being optimal from the standpoint of diversification. Adding stocks reduces diversifiable risk, but at a dimin- 
The superior investment properties of the market fund were long derided on the ground that comparisons between market and managed funds were hypothetical-the researcher was comparing the performance of actual portfolios with market averages that involved no administrative costs. But there are now market funds in operation. They charge management fees and incur custodial expenses that are known and transaction costs that can be estimated with fair accuracy. The total administrative costs of these funds are at most one-tenth of those of conventionally managed funds-and for substantial portfolios, proportionately so close to zero that they can be ignored in comparing the performance of managed and of unmanaged funds.

A final implication of the analysis worth reviewing concerns the best way of altering the risk-return characteristics of an investment portfolio. A pure market fund would have a beta of 1 and an expected return equal to the average return of the stock market (historically about 9 percent). If the investor desires a different risk-return combination, the most efficient way of achieving it is to combine his (equity) portfolio with very low-risk assets (e.g., Treasury bills) if he desires a lower risk and is willing to pay for it by accepting a lower expected return, or with borrowing (leverage) if he wants a higher return and is willing to accept a higher risk. Lending and borrowing, as methods of altering the portfolio's risk-return characteristics, are compatible with maintaining broad diversification. By contrast, if one simply created a high-risk/high-return portfolio by casting out low-beta stocks, the stocks remaining in the portfolio would not be optimally diversified. However, our primary concern in this article is with the equity portion of the trust portfolio.

\section{B. Trust-Investment Law}

We concluded in our previous article that the rules of trust law governing investment, when properly understood and applied, authorized fiduciary investment in market funds. We are not alone in reaching this conclusion: most investors in existing market funds are pension funds, which have been made subject to the prudent-investor standard of the Employee Retirement Income Security Act of 1974 (ERISA) $^{10}$

ishing rate; at the same time, it increases the administrative costs of the portfolio. Sponsors of market funds have followed different strategies. Wells Fargo has more than 480 stocks in its portfolio; essentially, it is matching the S\&P 500. Others are using statistical sampling techniques to duplicate the performance of the S\&P 500 with a smaller number of stocks, thereby reducing both transaction costs and, correlatively, the minimum efficient size of the fund. It seems too early to determine which approach is superior. See generally James H. Lorie, Diversification Old and New, J. Portfolio Mgmt., Winter 1975, at 25, 28.

10. ERISA sec. 404(a)(1)(B). 
as well as the common law standard, and presumably have been counseled that the new investment strategy is prudent. ${ }^{11}$

An examination of the various rules of trust-investment law in our previous article showed that market-fund investing complied with those rules. The case law of the 1930 s, which examined investments on a stock-by-stock basis rather than on a portfolio basis, was simply reviewing then-current investment practice. The cases do not require contemporary trustees to follow an investment strategy-individual stock picking with its consequent expense and underdiversification-of demonstrated futility. The Spitzer case, ${ }^{12}$ which recently caused a flurry of concern in trust-law circles by repeating (in dictum) the old learning that the prudence of an investment is to be determined on an investment-by-investment basis, qualified its dictum by emphasizing the importance of diversification-an emphasis inconsistent with simply looking at how each stock does individually and ignoring the performance of the portfolio as a whole. Moreover, Spitzer merely applies conventional case law to a conventionally managed portfolio with regard to investment transactions undertaken years before market funds became available. The issue was the standard one of the old law: assuming that the trustee's investment strategy is individual stock picking, were these particular selections prudent in the light of the circumstances? The Spitzer court was not asked to evaluate the prudence of an unmanaged market-fund approach. ${ }^{13}$

\section{OBJECTIONS TO THE MARKET-FUND CONCEPT}

Those who (to date) have objected to our approach have generally

11. According to Rex Sinquefield, vice-president, American National Bank, the bank has had private trust accounts employing market-matching strategy approved by the local Illinois courts where the bank does business.

12. Reported as In re Bank of New York, 35 N.Y.2d 512, 323 N.E.2d 700, 364 N.Y.S.2d 164 (1974), discussed in Market Funds I, supra note 1, at 24-25.

13. A good sign of the spread of the portfolio-as-an-entity approach to evaluating prudence is the recognition given it by the officer administering the prudent investor standard of ERISA. In a statement issued at the August 1976 convention of the American Bar Association, James D. Hutchinson, administrator of pension and welfare programs, U.S. Department of Labor, said:

Advocates of modern portfolio theory reject the view that focuses solely on the risky assets held by a plan and instead realizes that each investment should be evaluated in the context of the entire portfolio. Diversification is the key to this expanded concept of risk. To the extent that a portfolio is structured in a way that variation in the value or return of one security is offset by a variation in another, the riskiness of each individual investment is decreased.

The prudent investment manager, however, must arrive at what would be a suitable degree of risk for the particular plan before a portfolio can be constructed to meet its needs.

Erisa Boss Makes Major Statement on Prudency, Fiduciary Responsibilities, Pensions \& Investments, Sept. 13, 1976, at 37, 38. 
not argued that legal difficulties would defeat market funds if the fundamental economic concept were sound. ${ }^{14}$ Rather, they have challenged the concept itself. Accordingly, the objections that we consider here are not in the main legal objections, but go rather to the economic merits of the market-fund concept.

\section{A. What If Everybody Did It?}

The most frequent criticism of the market-fund concept points to the consequences that would result if every investor decided to follow it. The efficiency of the market, which is what makes a passive strategy rational, depends on the efforts of investors to outperform the market. It is these efforts, manifested in research and in trading, that keep the price of a stock always equal to the best current estimate of its true value. If all investors abandoned the search for overvalued securities to sell and undervalued securities to buy, how could one be sure that the market price of a stock was the best estimate of its true value?

This criticism of the passive strategy is both premature and, in ignoring the powerful self-correcting forces in the market, fundamentally misconceived. At a time when less than two-tenths of 1 percent of

14. A possible exception is an unpublished talk given by James Hamilton of Wertheim \& Co. at an Institutional Investor Conference on April 12,1976. Hamilton informed the audience that Wertheim \& Co. considered constructing and marketing an index fund in July 1972 but, after getting to the brink, abandoned the idea. The reasons for abandonment do not appear in a carefully formulated way, but review of the transcript of the extemporaneous talk leads to the following summary:

1. After distinguishing what the law is from what is should be, Hamilton expressed concern that "if our sense of what the fiduciary requirements are as opposed perhaps to what they would be is correct, then we felt that it was an unnecessarily risky path in these circumstances to pursue. ..." Thus, a business judgment about the risks inherent in trust-investment law prevented Wertheim from developing a market fund and might prevent fiduciaries from investing in them.

2. Hamilton said that in a legal contest between a deserving plaintiff and a perhaps affluent investment manager over a loss in a period of market decline, with the judge having to decide where to assign the loss, "you may visualize to yourself explaining capital market theory to the judge."

3. Hamilton cited the Spitzer case and said that "the court specifically negated the idea that any particular rate of return held you harmless against making an imprudent individual investment." The result would be to compel investment managers to look at in dividual securities.

4. Investing in market funds represented a clear departure from the prevailing custom in the business, increasing the risk of surcharge. It was concluded that until that custom changes, "let somebody else break the ground, frankly."

Point 1 is a judgment not everyone has made in that way; the major corporations that have been investing pension money in trust funds have certainly been counseled that trust-investment law permits them so to act. Point 3 has been refuted in Market Funds I, supra note 1, at 24-25; cf. text at note 10 supra. Point 2 seems somewhat patronizing of the judiciary, which has compiled a generally admirable record of adapting (slowly, to be sure) trust-investment law to changes in investment practice, e.g., the legitimation of trust investment in mutual funds, discussed in Market Funds I, at 20-22. Point 4 suggests that by declining to change its practices, the industry can, through prevailing custom, dictate to the courts what the future standard of prudent investment shall be; we discuss in text at notes $46-90$ infra why it would be hazardous for trustees to believe they can ignore the new learning with impunity. Hamilton also argued that there is nothing fundamentally new in market funds except the "statistical wrapping"; they constitute essentially a throwback to conceptions of portfolio construction current in the period before the "go-go" market of the mid-to-late $1960 \mathrm{~s}$. This point is incorrect as demonstrated in our first article. 
the nation's stockholdings ${ }^{15}$ are in market funds, it is premature to argue against further adoption of the concept-and indeed against the concept itself-on the ground that if 100 percent (or perhaps some lesser fraction) of the nation's investment assets were so managed, the stock market would cease to be efficient. No responsible observer thinks either that the very modest incursion of the passive strategy to date has undermined the efficiency of the market or that even a tenfold increase in the amount of assets in market funds would undermine market efficiency: such an increase would bring the fraction of assets under such management to at most 2 percent.

The market could absorb much higher fractions of passive investment without any perceptible decrease in efficiency. No one knows just how much stock picking is necessary in order to assure an efficient market, but comparison with other markets suggests that the required amount is small. In markets for consumer durables, homes, and other products, unlike the securities markets, the amount of search is highly variable across consumers, many of whom do little or none; trading may not be frequent (e.g., homes); products may not be homogeneous (no two homes are as alike as all the shares of the same common stock); bids and offers may not be centrally pooled so as to maximize the information available to buyers and sellers. Yet these markets are reasonably efficient, albeit less so than the securities markets. The movement toward passive investment strategy would have to proceed very far indeed before it impaired seriously the stock market's efficiency.

Moreover, it is not our position that all trustees must immediately place all of their common stock holdings in market funds. In our opinion, as of today prudence requires at most that trustees gradually increase the proportion of the trust assets placed in such vehicles, though in our judgment it permits them (perhaps with the exception of the very largest) to shift at once the entire equity portions of their portfolios into market funds. Not all trustees, of course, will exercise the option of putting the entire equity portion of their portfolios into market funds; at best, the fraction of investment assets so managed will grow gradually. There will be many points at which it will be possible to pause and evaluate the continued efficiency of the market. We are far from having reached even the first of these assessment points.

15. A recent estimate computes that about $\$ 1$ billion in pension assets is now in market funds. Index Fund Approach Claims a New Convert, Pensions \& Investments, Sept. 13, 1976, at 15. The market value of total stock outstanding as of 1975 was $\$ 816.3$ billion. Securities and Exchange Commission, Office of Economic Research, Statistical Reference Tables for the Month Ending July 1976, at 61 (1976). 
Those who argue that the stock market might be rendered inefficient by a pell-mell rush to invest in market funds ignore the inherently self-limiting character of the process whereby investment assets are being shifted into market funds. If the process ever reached the point where it rendered the market inefficient, this would imply the existence of opportunities for investors to increase portfolio performance by research and trading. Some investors (though not necessarily trustees) would increase their search activities to take advantage of these opportunities, and the higher level of such activities would restore market efficiency.

To be sure, if all or a very large fraction of investors were legally prevented from engaging in stock picking, the market's self-correcting mechanism might fail. Fortunately, there is no prospect of that-and there would be none even if trust law were interpreted to require all trustees to adopt a passive strategy. At present all trust and institutional stockholdings constitute only 40 percent of the market value of total stockholdings. ${ }^{16}$ Although further growth in the relative position of pension trust funds is predictable, it is unlikely that anywhere near 100 percent of the nation's investment assets will ever be controlled by trusts.

Moreover, we neither foresee nor counsel a rule forbidding trustees to engage in stock picking in any or all circumstances. The furthest we see the law moving in this direction is eventually to require any trustee who rejects the passive strategy to give reasons for doing so. If the passive strategy were rejected for a good reason-such as a decline in the stock market's efficiency that has created an opportunity for obtaining a higher risk-adjusted return by stock picking than through a market fund, or a persuasive record of beating the market-the trustee would not be deemed in breach of trust. The evidence thus far is that few trustees could justify rejection of the passive strategy on either ground.

The frequent confusion of the "what if everybody did it" critics of the market-fund concept is typified by a recent article in the Columbia Law Review. ${ }^{17}$ The author states that the concept makes sense as an investment strategy "only for so long as most investors eschew it." 18 But he offers no evidence or reason to believe that "most" as opposed to "some" or "a few" investors must be active stock pickers in order

16. Id.

17. Harvey E. Bines, Modern Portfolio Theory and Investment Management Law: Refinement of Legal Doctrine, 76 Colum. L. Rev. 721, 777-79 (1976).

18. Id. at 777 (emphasis added). 
for the passive strategy to yield superior performance results, and his own discussion of the effects of widespread adoption of the passive approach is prefaced by the clause "if everyone began investing this way ...."19 A footnote on the same page takes still a third position: the efficiency of the market would be seriously endangered if a large fraction of investors (apparently less than one-half, as distinct from "most" investors, or "everyone") were to adopt the passive strategy. ${ }^{20}$

In another recent article, Humbach and Dresch ring further changes on the "what if everybody did it" theme. ${ }^{21}$ But, apart from a significant concession that market matching is indeed a more profitable investment strategy than stock picking, ${ }^{22}$ their article is an unconvincing string of conjectures. The first is that after most investors are stampeded into adopting the passive strategy by realization of its superior profitability, the only investors left to pursue an active strategy will not be "representative"-and may in fact be "practically risk oblivious, not unlike horse bettors who know that the odds are always substantially against them but hope to beat the odds nonetheless." 3 The authors are worried that these gambler-type investors will undervalue all but the riskiest securities. But, if so, this would mean that the safer securities were available at bargain prices, and investors not having the gambling mentality would resume an active strategy in order to identify and purchase the undervalued securities. Humbach and Dresch ignore the self-correcting mechanism of the market.

They next speculate that "because the market fund strategy can be used only by investors or investor pools having large amounts of capital," the very investors who withdraw from active trading will be those who have the greatest resources for gathering information with respect to the correct valuation of securities. ${ }^{24}$ But this is just another way of saying that widespread adoption of the passive strategy threatens the efficiency of the market. It does not. If the disinvestment of resources now employed in futile efforts to beat the market ever proceeds to the point where the market can be beaten, that will be a signal for some investors to resume the active strategy. Moreover, many large investors are not fiduciaries; no interpretation of trust law can prevent

19. Id. at 778 (emphasis added).

20. Id. at 777-78 n.173.

21. John A. Humbach \& Stephen P. Dresch, Prudence, Information and Trust Investment Law, 62 A.B.A.J. 1309 (1976). See John H. Langbein \& Richard A. Posner, Market Funds and Efficient Markets: A Reply, 62 A.B.A.J. 1616 (1976), for a reply to their article.

.22. Humbach \& Dresch, supra note 21 , at 1311-12.

23. Id. at $1310-11$.

24. Id. at 1311 . 
them from continuing to employ armies of securities analysts if they believe that their great resources enable them to outperform the market.

The third point made by Humbach and Dresch echoes the Columbia Law Review article at its most extreme: "Active selection, rejection, and rearrangement of portfolios-that is, active, informed trading-is constantly required of all investors if the market's equilibrium and capital allocations are to be based on the maximum possible input of information and attitudes." 25 Strictly, this is a tautology: the defection of even one investor from the ranks of the active traders would reduce the amount of information generated by the market below the maximum amount. But Humbach and Dresch seem to mean more: that it is desirable for every investor to try to beat the market, however futile the endeavor. It cannot be correct, however, that every further increment of securities information yields a social benefit greater than its cost. The optimum account of market information is surely not infinite. At some point the cost of additional information must outweigh the social gain. The evidence is that this point has been reached-in fact, passed.

The passive strategy is a method of economizing on information and transaction costs. Humbach and Dresch come perilously close to suggesting that all economizing strategies relating to market transactions are socially undesirable. Should consumers never rely on the experience of a friend, the advice of a travel agent, a seller's reputation? These are all devices for economizing on consumer search costs. Do Humbach and Dresch deprecate these examples of passive strategy? Would they support a rule that every consumer must shop a minimum of 12 car dealers before buying a car? It is true that if all consumers, whether of automobiles or of common stock, abandoned active search, serious inefficiencies would result-were it not for the natural self-corrective capacities of markets, which assure that efforts at economizing on search costs will not be carried to the point where the market ceases to be efficient. This factor is ignored by Humbach and Dresch, as by the other "what if everybody did it" critics.

Humbach and Dresch admit that they have no evidence that adoption of the passive strategy by many or even all trustees would reduce the efficiency of the stock market significantly. They admit that the costs of existing levels of research and trading may exceed the benefits in increased market efficiency. ${ }^{26}$ Yet they ask trustees to 
continue following an admittedly unprofitable strategy to avoid the wholly conjectural social costs of "abstention." 7 They fail to realize that if these costs materialized-if the efficiency of the market declined to the point where increased search would yield a positive expected return, rather than negative as today-some passive investors would shift back to an active strategy, and this process would continue until the efficiency of the market was restored.

\section{B. Effects on Capital Formation}

Some concern has been voiced that the adoption of the marketfund concept by institutional investors would reduce the rate or distort the pattern of capital formation, with adverse consequences for the overall efficiency of the economy. One version of this argument is that investors adopting the strategy will perforce invest solely in alreadyestablished firms, thus starving new ventures of risk capital. The frightening picture is presented of a society in which all of the major investors invest in the same relative handful of well-established firms and there is no capital to finance new ventures.

This argument assumes, however, that trustees are both an appropriate and a quantitatively important source of risk capital for new or untried ventures. We doubt both premises. Traditionally, the trustee has not been regarded as an entrepreneur. Trustees are generally not compensated for taking entrepreneurial risks or for being able to spot promising new ventures; they tend to be selected for reliability in preserving the capital of the trust rather than for flair in speculating and taking risks. The conservatism of trust investing is the common ground of both old and new, active and passive, theories of trust investment. If anything, the passive strategy, with its emphasis on diversification, is likely to broaden the existing investment choices of trustees. Trustees who follow conventional investment strategies tend to concentrate their investments in a much shorter list of stocks than would be considered prudent under modern capital market theory.

A more substantial question is presented if the focus shifts from investment by trustees to investment in general. If every investor both adopted the passive strategy and used the identical list of stocks to determine the composition of his portfolio, there would be no venture capital available either for new enterprises or for unlisted enterprises. However, such a prospect is remote. As more and more investors shifted their assets into the stocks of well-established firms, new or small enter- 
prises would have to pay a higher premium in order to attract capital. This premium would induce capital to flow away from the well-established firms to the newer or smaller firms. Eventually an equilibrium would be reached at which the amount of risk capital supplied was equal to the demand for it. We are not dealing in conjecture; after all, present capital markets (broadly defined to include all sources of business capital) provide financing for both General Electric and the corner delicatessen.

The capital-formation argument is really a version of the previous argument-that is, that all investors will adopt the passive strategy, a prospect not only remote in time but wholly unrealistic given the selfcorrecting mechanism of the stock market. Opportunities for exploiting demands not met by a passive investor will be met by other investors, in whatever mixture of active and passive investment is most efficient.

\section{Increasing the Gulf Between Ownership and Control in the Large Corporation}

It may be argued that the passive strategy would aggravate the various problems that are alleged, in an extensive literature, to result from the divorce between ownership and control in the large corporation. ${ }^{28}$ The corporation is owned by its shareholders, but the practical day-to-day control of the company is in the hands of hired managers who, to the extent that they are free from effective shareholder control, can run the corporation for their own benefit, with resulting harm to the shareholders and perhaps to the efficiency of the firm. Arguably, this problem would be aggravated by widespread adoption of the passive strategy since even fewer corporate owners than at present would be exercising oversight of managerial performance. ${ }^{29}$

The premise of the argument is debatable. While corporate shareholders are not in effective control of the day-to-day management of major corporations, it does not follow that hired managers are free to conduct corporate affairs in any manner they like or that they do not as a rule act in the interest of the shareholders. This is not the place to rehearse in detail the arguments that have been made pro and con on

28. Concern with these problems received its classic early expression in Adolph A. Berle, Jr., \& Gardiner C. Means, The Modern Corporation and Private Property (1932, rev. ed. 1968). For recent discussion see, e.g., Oliver E. Williamson, The Economics of Discretionary Behavior: Managerial Objections in a Theory of the Firm (1964); Armen A. Alchian, The Basis of Some Recent Advances in the Theory of Management of the Firm, 14 J. Indus. Econ. 30 (1965).

29. The passive strategy, taken to its logical extreme, would appear to require abstention from participation in proxy fights, shareholder derivative suits, and all other devices for challenging management since a decision to participate would entail some research and/or transacting by the trustee-shareholder. 
this issue, ${ }^{30}$ but one should note the considerable harmony of interests between managers and shareholders (especially where managerial compensation is based on corporate performance), the effect of competition in the corporation's product markets in constraining managerial discretion, the pressures exerted by creditors (especially large lenders), and the existence of various mechanisms for displacing unsatisfactory management, notably the tender offer (take-over bid).

Current discussion of the market for corporate control focuses on the tender offer, in part because the effectiveness of the tender offer as a method of corporate take-over does not depend on the degree to which stockholders are involved in the actual management of the corporation's business. A firm (or group of individuals) seeking to take over another corporation simply offers a price for that corporation's shares that exceeds the current market price of the stock. Shareholders who consider the price attractive will tender their shares; if enough shares are tendered the offeror will take control of the corporation and will be able to install a new management. Given this straightforward (though, thanks to SEC regulation, increasingly costly) method of removing corporate assets from the hands of inefficient or dishonest managers, it may be questioned how serious the problem of lack of managerial accountability to the capital markets is today. ${ }^{31}$

But what if a majority of a company's stock were held by institutions committed to the passive strategy-institutions that engaged in no trading whatsoever (except as necessary for redemptions or to maintain the desired level of diversification)? If another company believed it could manage that company's assets more profitably than the present management, how would it go about obtaining majority control? If it approached each of the (passive) institutional investors with an attractive tender offer, presumably they would refuse to sell, on the ground that their policy was never to sell any stock except when necessary for purposes of redemption or diversification. Existing management, however dishonest or inept, would be immune from the threat of take-over because a majority of the shareholders would refuse to consider any offer to sell their stock.

Although this is a potential problem worthy of concern, it can be solved by a slight modification in (or clarification of) the decision rules governing passive investors, including trustees, so as to permit (indeed,

30. See Henry G. Manne, Mergers and the Market for Corporate Control, 73 J. Pol. Econ. 110 (1965).

31. A few corporations (e.g., AT\&T, IBM) may be so large that no investor or syndicate of investors, private or corporate, could be expected to make a successful tender offer, at least without raising serious antitrust problems (e.g., if IBM tried to take over AT\&T). 
presumptively to require) the investor to accept the (highest) cash tender offer if it is significantly above the market price of the stock. ${ }^{32}$. This approach seems congenial to the assumptions of the passive approach, which posits that the current market price of a stock is the best estimate of its true value. If the market price of a share of stock is $\$ 20$ and a tender offer of $\$ 30$ is made, the inference from modern capital market theory is that $\$ 20$ is the best estimate of the value of the corporation's stock under present management and therefore a price of $\$ 30$ is presumptively an attractive one at which to dispose of the stock. Typically in take-over situations the defending management will argue that the stock of the corporation is undervalued-not only at its current price but at the (often much) higher price offered by the firm seeking to take over the corporation. This argument has a hollow ring from the standpoint of efficient-market theory.

While it is thus a reasonable extension of the passive strategy for the passive investor to respond affirmatively to tender offers, he should not be required to accept the first tender offer made. He should sell at the highest possible price. Often there will be a succession of competing tender offers bidding up the price of the stock. He will have to determine when the bidding process has been completed.

There is an argument for declining tender offers. It runs as follows: if the offeror offers $\$ 30$, he must-unless he is a "raider"33 -think the value of the stock will exceed $\$ 30$ if he obtains control; therefore the shareholder should decline to tender, since the stock is really worth more than the tender-offer price. Moreover, if he does sell his stock, he may have to buy it right back in order to maintain his desired level of diversification. However, by declining the tender offer, the shareholder (depending on the size of his holdings) may defeat the take-over bidand then he is $\$ 10$ a share poorer. It would seem therefore that any shareholder (including a trustee) who has such a large share of the company's stock that his refusal to tender might defeat the take-over attempt would be well advised to accept the best tender offer, though he need not tender more shares than sought by, or necessary to, the

32. The result should be the same if the offeror offers securities rather than cash, as long as the securities are either heavily traded or readily convertible into heavily traded securities, so that their value is easily determined and realizable. Tax considerations would limit the operation of the presumption in some cases; e.g., a taxable trust holding low-basis stock may have good reasons for not wanting to recognize a capital gain at the time of the tender offer.

33. A "raider" is someone who plans to misappropriate the corporation's assets for personal gain. Such behavior will force down the price of the corporation's stock, at least in the long run. We assume that there is sufficient enforcement of corporate managers' fiduciary obligations to shareholders to make raiding a fairly uncommon motive for take-overs, at least of the substantial firms likely to be held in a market fund's portfolio. 
offeror. But the wisdom of attempting these nice strategic calculations depends on their cost, and most trustees will be better advised, we suspect, to adopt an automatic policy of responding affirmatively to tender offers.

A related question is that of the trustee's optimal expenditure of time and money on deciding how to vote on merger, squeeze-out, and related management proposals that might reduce (or enhance) the value of the trustee's holdings. The well-diversified trustee may conclude that the net gains from researching these questions is negative-so long as a majority of the stock of a corporation in which he has invested is not controlled by passive investors. Should a time come when there are corporations so controlled, the prudent trustee may decide that the active exercise of his rights as a shareholder is appropriate to protect his investment from management overreaching. The problem, however, is at present remote and conjectural.

This problem aside, once the decision rule that we have advocated were adopted, the concern that the market-fund concept might result in aggravating the alleged separation of corporate ownership from control would disappear. Indeed, the passive investor's automatic rejection of management claims that the current price of the corporation's stock is less than the "true" value of the stock would promote the operation of the market in corporate control. The passive investor who utilizes the decision rule urged here would be quicker to respond to take-over bids than the conventional investor who listens carefully to the management argument that the tender-offer price undervalues the corporation's stock.

\section{D. "Accepting Mediocrity"}

A common argument against the market-fund concept is that it involves an undignified and defeatist acceptance of mediocre performance results. Even if investment managers have not been able thus far to outperform the market, for them to admit the futility of their efforts would be a "cop out," dooming the investor and investment beneficiary to perpetual mediocrity. The "search for excellence," however difficult and likely to fail, is said to be preferable. But the investor who had followed the passive approach would in the long run have outperformed most institutional investors. A true search for excellence would have led investors to adopt the buy-the-market-and-hold strategy; it is conventional management that, on the historical record, represents the "acceptance of mediocrity."

Perhaps those who make the argument have a slightly more subtle point in mind, that accepting the passive strategy might lead the invest- 
ment community to abandon its efforts to improve investing knowledge and techniques. In this view, adoption of the passive strategy is comparable to the abandonment of research on the treatment of multiple sclerosis on the ground that the search has thus far been in vain. But we certainly do not advise all investors to abandon efforts to improve their investment performance; nor, we repeat, is there any prospect that all investors will adopt the passive approach. Many investors will continue to try to outperform the market, and, to the extent that they succeed, their methods will be emulated by other investors. Indeed, an important function of market funds-one recognized even by their detractors-is to provide yardsticks (realistic ones, since market funds, unlike the market indexes such as the S\&P 500, involve actual administrative costs) for judging the performance of managed funds and thereby spurring them to greater efforts at improvement.

\section{E. Professor Murray's Objections to Market Funds}

In general, the controversy over market funds pits the academic against the investment community, with the former supporting the market-fund principle and the latter typically opposing it. A notable exception to the academic support for the market-fund idea is Professor Roger Murray of Columbia, who in a recent paper offers "five reasons why it is fair to say that the index fund is an idea whose time has passed." 34

First, he believes that the S\&P 500 (the most commonly used index for constructing a market fund) outperformed conventionally managed funds in the 1973-74 bear market only because the S\&P 500 is heavily dominated by financially strong companies, which impart low volatility (beta). to the index. A portfolio that has a beta of 1 (the beta of the S\&P 500) will rise or fall at the same rate as the stock market (i.e., NYSE) as a whole, since the beta of the market as a whole is also 1. In contrast, a portfolio having a beta of 1.1 will rise 10 percent faster than the market in a rising market and fall 10 percent faster in a falling market. Murray argues that the S\&P 500 did well during the 1973-74 bear market only because its beta of 1 was lower than the beta of many conventionally managed funds and it is a characteristic of a low-beta fund to do relatively well in a period of generally declining stock prices, that is, to fall more slowly than a high-beta fund. He

34. Roger F. Murray, Investment Risk in Pension Funds: The Pension Benefit Guaranty Corporation View, in Evolving Concepts of Prudence: The Changing Responsibilities of the Investment Fiduciary in the Age of ERISA 37, 39 (Financial Analysts Research Foundation, 1976). 
concludes: "Because of its weighting, the [S\&P] index portfolio [i.e., market fund] will always tend to do better in a declining market but not as well in a rising one. Since the periods of rising prices tend to exceed the periods of falling prices, an index fund is a formula for a solid, consistent, long-term loser. Who needs that? Why is that prudent?"3 5

This argument is factually incorrect. In the last two bull markets, the S\&P 500 outperformed all categories of mutual funds whose systematic risk was as great as or greater than that of the S\&P 500 with but one exception. ${ }^{36}$ Thus, contrary to Murray's claim, the S\&P 500 appears to have substantially outperformed the mutual fund industry even in rising markets.

Also, Murray's argument reveals a fundamental misunderstanding of modern capital market theory. It is true that a fund with a beta greater than 1 will tend to do better in a rising market than one with a beta of 1 and-the same point really-that the expected return of the riskier fund will be higher than that of the less risky fund. This is but an aspect of the fundamental principle of capital theory that systematic risk and expected return are positively correlated. What Murray overlooks is that, since the higher risk is a negative factor to the risk-averse investor, there is no presumption that the higher-risk/higher-return portfolio yields the investor greater utility. Indeed, the logic of his argument is that investment managers should strive to maximize beta in order to maximize investors' expected returns. But this would be a sound strategy only if investors were risk neutral (and a fortiori if they were risk preferring). Since most investors are risk averse, there is a trade-off between high risk and high return, and the fact that one portfolio has a lower beta than another does not make it a "solid, consistent long-term loser"; it simply makes it a less risky investment vehicle and, correlatively, one that is expected to yield a lower return.

35. Id. at 39.

36. The following table compares the performance, in the last two bull markets, of the S\&P 500 with the four categories of mutual funds having betas equal to or higher than that of the S\&P 500. The table shows that, even in rising markets, the S\&P 500 outperformed the fund categories (arranged from left to right in order of declining beta) in seven out of eight possible comparisons:

\begin{tabular}{cccccc} 
& & \multicolumn{4}{c}{ Mutual Fund Group } \\
\cline { 3 - 6 } Period & $\begin{array}{c}\text { S\&P } 500 \\
(\%)\end{array}$ & $\begin{array}{c}\text { Venture Capital/ } \\
\text { Special Situations } \\
\text { (\%) }\end{array}$ & $\begin{array}{c}\text { Aggregate } \\
\text { Growth } \\
(\%)\end{array}$ & $\begin{array}{c}\text { Growth } \\
(\%)\end{array}$ & $\begin{array}{c}\text { Growth }+ \\
\text { Income } \\
(\%)\end{array}$ \\
\hline June 1970-Dec. 1972 $\ldots$ & +75.6 & +55.1 & +73.5 & +75.4 & +63.0 \\
Sept. 1974-June 1976 $\ldots$ & +76.7 & +81.1 & +70.9 & +68.1 & +75.1 \\
\hline
\end{tabular}

Source: Robert Levy (Computer Directions Advisors, Inc.). 
A market fund is superior to a conventionally managed fund, not because it is less or more risky than the conventionally managed fund, but because at any given level of risk-and through appropriate doses of borrowing or lending, a market fund can in principle be made as risky or safe as the investor desires-the market fund yields a higher net expected return owing to its superior diversification and lower transaction costs.

Murray's second argument is that since the S\&P 500 is limited to "seasoned listed common stocks," tracking the S\&P 500 "is not necessarily equivalent to an average return from equity investing." 77 This is true but it is not a proper criticism of the market fund. For many investment purposes it may be undesirable to attempt to approximate the performance of equity investment as a whole." Equity investing includes investments in unlisted securities, some issued by closely held corporations, in circumstances where there may be no basis for presuming that the market is efficient enough to protect the passive investor. Although the S\&P 500 is not the last word in devising indexes to which to gear the passive strategy, that there may be superior indexes is not a criticism of the passive strategy as compared with conventional management.

Pointing out that the market-fund concept is "most strongly advocated by those who believe that the market is so efficient that there are no persistent returns to security selection," Murray acknowledges that "on average, this is easily shown to be true. Positive deviations from the average are difficult to achieve for sustained periods." 38 This is an argument for the wisdom and prudence of the passive strategy, for if it is difficult to achieve persistent above-average performance, attempting to do so may not be a realistic goal for trustees. But Murray continues: "the 37-year record of the Chemical Fund suggests that it is not impossible." 39 The Chemical Fund is the only institutional investor thus far brought to our attention that has outperformed the market (on a risk-adjusted return basis) for an extended period of time. Its success is consistent with the law of averages: one out of several hundred investors could turn in a consistently better performance even if all were employing purely random investment policies. There is also a question whether Chemical Fund's performance is in fact superior to the market's when returns after load charges and

37. Murray, supra note 34 , at $39-40$.

38. Id. at 40.

39. Id. Professor Murray is a director of Chemical Fund. 
capital gains taxes on portfolio turnover of an investor in the Chemical Fund are compared with the (hypothetical) experience of an investor in a market fund. Finally, even assuming that Chemical Fund has in the past outperformed the market because of superior stock picking, it does not follow that it will continue to do so. ${ }^{40}$

Furthermore, the advocates of market funds do not claim that no investor has ever been able to beat the market (other than through being lucky). The argument is rather that the probability of outperforming the market is so small, especially for institutional investors, that the attempt is a futile one. The experience of the Chemical Fund, by its very atypicality, supports this argument. If one institutional investor (or a very few) out of hundreds consistently outperforms the market, that is hardly an adequate basis for a trustee's attempting either to outperform the market himself or to identify an institutional investor that is likely to outperform the market in the future. Murray has suggested no procedure by which an investor can identify the conventionally managed fund that is likely to turn in a superior performance.

Murray further argues that "it would seem a matter of almost elementary prudence to reduce the stock portfolio's volatility at high levels of the market and to increase it at low levels." 41 However, any investor who knew when the market was at (or near) its high or low points would rapidly become a very wealthy man-especially now that option trading allows that seer such phenomenal leverage. The ability to time market turns is as elusive as the ability to select the undervalued stock to buy or the overvalued stock to sell. Indeed, there is no sharp conceptual or practical distinction between stock picking and market timing. The statement that the market has reached its peak and is about to decline, or that it has bottomed out and is about to rise, is simply a statement that most common stocks are overvalued or undervalued.

It is true that the empirical studies of conventionally managed funds have in general not distinguished between timing and individualstock-picking judgments as factors in the poor performance of the funds. It is conceivable that conventionally managed funds have done better at timing than at picking, but it is unlikely. ${ }^{42}$ The difficulties of timing are suggested by the earliest version of the efficient-market theory-the theory of the "random walk"-which taught that market

40. Chemical Fund's second-quarter 1976 report to its shareholders discloses that Chemical Fund underperformed the S\&P 500 for the first half of 1976.

41. Murray, supra note 34 , at 40 .

42. See William F. Sharpe, Likely Gains from Market Timing, Financial Analysts J., Mar./Apr. 1975, at 60. 
movements follow a random pattern. We know of no institutional investors that have mastered the principle of order underlying the apparent randomness of market turns.

Murray's last criticism of the market-fund concept is a reprise of his previous point: "Looking ahead through a rear-view mirror is a regrettable habit of asset managers.... It would have been better in some past period to own the index.... Therefore, the manager modifies his present program to accommodate the prior period's exposure. If one believes, as I do, that common stocks are undervalued..., he would not own the index fund." 33 This is simply a claim that market turns can be forecasted and that Professor Murray is a superior forecaster. Even if he really is one of those rare investors (or investor-advisors) who can outperform the market, the implications for sound investment strategy are unclear.

\section{APPROPRIATE QUALIFICATIONS OF THE PASSIVE STRATEGY}

Our position is sometimes caricatured as one of urging that all the trustees in the country tomorrow set about creating, or purchasing shares in, market funds designed to approximate the performance of a market index such as Standard and Poor's 500. We have never advocated such a position. Although conventional investment strategies have proved to be unsuccessful when judged by the findings of modern capital-market theory, it would be inconsistent with the fundamental, and wholly appropriate, conservatism of trust-investment law to counsel a wholesale and precipitate abandonment of the conventional strategy for the new market-fund approach. The simultaneous defection of all or most trustees from conventional to passive investment strategies could have consequences for securities prices; and while we have no reason to think these consequences would be significant, or adverse, or if adverse more than temporary, we do not advise the trust community to assume even the slight risks that such a sudden abandonment of conventional methods would entail. We advocate only a gradual movement toward adoption of the passive strategy, with many opportunities to pause and reflect along the way on the continued validity of the concept as it may be affected by the concentration of more and more investment assets in market funds.

Accordingly, our view of an appropriate immediate step for the prudent trustee would be for him to place a modest fraction of his investment assets in market funds. This is precisely what the Bell tele- 
phone companies, Exxon, Ford Motor Company, Interlake, and several other large pension trustees have done. Although smaller trustees may wish to move 100 percent into market funds, knowing that their assets are too small to have any impact on the performance of the stock market as a whole, giant banks and pension funds will doubtless move more slowly and experimentally. Moreover, we are speaking only of the equity component of the trust assets. We have never urged that trustees should place all or most, or for that matter any part, of the trust assets in common stocks. That depends on liquidity needs, attitude toward risk, and tax considerations, among other things. Our argument is only that a gradually increasing portion of the assets that are allocated to equity market investment should be placed in market-fund vehicles.

Further, the NYSE list represents only an interim basis for structuring market funds. There is no reason in principle to limit the choice of securities to those listed on any particular exchange, even the world's largest. To the extent that the performance of securities listed on other exchanges, here and abroad, or on no exchange, are not perfectly correlated with the performance of the stocks listed on the NYSE, there would be gains in diversification from including in the trust portfolio some of these other securities. But these gains must be weighed against the additional transaction costs as well as the danger that some of these other markets may not be efficient; in many cases the data available on the performance of securities on other stock exchanges may not yet be adequate to enable one to make a confident judgment on the efficiency of those markets. ${ }^{44}$ For now, the important point is that the NYSE represents an enormously diversified array of equity-investment possibilities and that a market fund based on the NYSE list is a superior investment vehicle to the conventional equity-investment alternatives available to the trustee. But we do not foreclose the possibility that, as our knowledge grows, more broadly diversified portfolios than those based on the NYSE list (or a proxy thereof such as the S\&P 500) ${ }^{45}$ will be devised for trustee investment.

A compromise between conventional and passive investment strategies appears increasingly attractive as an interim position for the conservative trustee: the "core/noncore" concept that has been devised

44. For some evidence that European stock markets are efficient, see Gerald A. Pogue \& Bruno H. Solnik, The Market Model Applied to European Stocks: Empirical Results (M.I.T., Sloan School Working Paper No. 657-73, May 1973). Batterymarch Financial Management Corporation has begun to offer a foreign market fund.

45. It is noteworthy that the S\&P 500 has recently been revised to include some major financial and non-NYSE (including over-the-counter) stocks, such as American Express and Anheuser-Busch, in place of the stocks of several industrial corporations, railroads, and utilities dropped from the index. 
by the financial intermediaries that currently offer market funds. Its advocates contend that one of the reasons why conventionally managed funds are unable to beat the market is that the portfolio manager has too many irons in the fire. Because the diversification policy of most institutional investors requires them to hold a number of different stocks, every time they make a trade based on superior information or judgment they may have to make an offsetting trade in some other security in order to maintain the desired diversification. But the second trade may not be based on superior information or judgment, and hence may impose on the fund transaction costs not offset by any profit from the trade. This problem can be overcome if a market fund is regarded as the core of the investor's portfolio, with a periphery consisting of securities that are traded under conventional stock-picking principles pursuant to research that suggests opportunities for beating the market. This approach frees the portfolio manager to select his area(s) of investment expertise explicitly and leave the other investment areas alone; he is under no pressure to make trades based on insufficient information or inadequate judgment. In particular, it allows him to devote attention to securities not now followed by the institutional investors' securities analysts because of their (futile) concentration on a handful of major corporations. Finally, the performance of the core is a yardstick for judging the manager's performance in the area in which he exercises choice.

Although this theory may be no more than the last-ditch stand of the security analyst, it is not absurd, and we see no reason why trustees ought not to be free to adopt it. That it involves a major commitment to the passive strategy is a point in its favor. Moreover, it offers a further opportunity to demonstrate the comparative merits of passive versus active investment strategies. As long as the fund monitors the performance of the core and of the periphery separately, and makes appropriate adjustments for any differences in risk (so that returns are always risk adjusted and hence comparable), the managers and beneficiaries of the fund will be able to test in a real-world setting the merits of the respective strategies. We conclude that investment based on the core concept is a prudent interim step toward a possible eventual goal of 100 percent trust investment in passive market-fund vehicles.

\section{IMPLICATIONS FOR CONVENTIONALLY MANAGED FUNDS}

We have thus far been discussing the economic background and investment-law justification of market funds. But the new understanding of the behavior of capital markets that lies behind the market fund also casts a shadow over the investment practices of conventionally managed 
funds. We raised this point briefly in our former article, warning that a trustee who failed to procure the advantages of market funds for his beneficiaries might one day find his conduct difficult to justify in surcharge proceedings; we expand our discussion here.

The superior performance of market funds has, as we have seen, two components. First, market funds enable enormous reductions in administrative costs to be achieved by eschewing research and minimizing turnover. Second, market funds enable superior diversification, thereby eliminating the uncompensated risk created by holding too few stocks. Capital-market research has shown that optimal diversification is not achieved unless the portfolio contains several hundred properly selected stocks. ${ }^{46}$ Most conventional funds hold far fewer stocks, in part because of the expense of researching so large a list, and the stocks they do hold are not selected with a view toward achieving optimal diversification. ${ }^{47}$

The question whether courts may some day compel fiduciaries to cease stock picking and adopt instead a market-matching strategy in strict conformity with the new learning has been raised, but it will require years of experience with passive investment to answer it. The timelier question posed for conventionally managed funds by the advent of the market fund is whether they may continue to subject their beneficiaries to the uncompensated risk of substantial underdiversification. Trustees are already under a legal duty to diversify their investments; modern capital-market research adds new particularity and extent to that duty. Trustees may not yet fear being subjected to a duty to match the market, but we think they may well be subjected to a duty to diversify across so many stocks that market matching may be the only way for most of them to discharge the duty without incurring either prohibitive research costs or liability under the Spitzer principle of responsibility for the performance of individually picked stocks. ${ }^{4}$

\section{A. The Duty to Diversify Trust Investments}

The trustee's duty to diversify investments is a familiar principle of modern trust law, codified in the Restatement of Trusts (Second). ${ }^{49}$ The duty is an outgrowth of the nineteenth-century change in trustinvestment law that permitted trustees to invest in corporate securities.

46. See Lorie, supra note 9 , at $25,28$.

47. Plainly, the number of securities held in the portfolio is not a guarantee of adequate diversification. A portfolio composed of 100 oil stocks would be less diversified than a portfolio of 25 stocks selected with some regard to balance among the industries represented.

48. See text at note 8 supra.

49. Restatement of Trusts (Second) sec. 228 (1957). 
(As long as trustees were limited to investing in essentially risk-free government issues, diversification was neither possible nor necessary.)

The duty to diversify was initially formulated simply as an application of the prudent-man standard of trust investment. The leading case, Dickinson, Appellant, ${ }^{50}$ arose in Massachusetts, the jurisdiction that pioneered the prudent-man standard. The trustee of a $\$ 16,000$ fund had invested $\$ 3,500$ in Union Pacific Railroad stock in May 1881. The following August he invested a further $\$ 2,500$ of the fund in the same issue. The shares declined. In an accounting in 1888, the equity court surcharged the trustee for the whole of the investment in the railroad, apparently on the theory that the shares were too risky for prudent investment. The Supreme Judicial Court reversed in part. Although it felt that the trustee had taken "a considerable risk to invest any part of a trust fund in the stock of such a road," the court was unwilling to decide "that the trustee so far failed to exercise a sound discretion that the investments should be held to be wholly unauthorized." 1 But the court disallowed the second purchase of Union Pacific shares. The first purchase constituted "an investment of between one fourth and one fifth of the whole trust fund in this stock, and is certainly a large investment relatively [sic] to the whole amount of the trust fund to be made in the stock of any one corporation." 52 In making the second purchase, the trustee was not "justified in investing in such stock as this so large a proportional part of the property." 33

The Dickinson case held that an investment rightful in type could be wrongful in amount. A trustee could buy too much of a good thing. Yet the court had very little to say about how much was too much. It referred to evidence taken in the lower-court proceeding showing that "conservative trustees" would not place more than 5 percent of a trust fund in one common stock, ${ }^{54}$ yet sustained a much larger investment. The inference seems inescapable that the court fastened on the fortuity of the trustee's having made two distinct purchases to decide that $\$ 3,500$ was prudent while the further $\$ 2,500$ was not.

The duty to diversify entered trust-investment law, therefore, as a commonsense notion, which in later cases never developed beyond the intuitive idea that the trustee ought not put all his eggs in one basket. The Restatement rule reflects the generality and imprecision of the case

50. 152 Mass. 184, 25 N.E. 99 (1890).

51. Id. at 188.

52. Id.

53. Id. at 189.

54. Id. at 185. 
law. The rule states in its entirety: "Except as otherwise provided by the terms of the trust, the trustee is under a duty to the beneficiary to distribute the risk of loss by a reasonable diversification of investments, unless under the circumstances it is prudent not to do so." 55

The case law on the duty to diversify is sparse, probably because corporate trustees traditionally insist upon being granted broad investment discretion before accepting trusteeships. As early as the Dickinson case, where the court approved an investment of more than 20 percent of the fund in a single issue, there was evidence that "conservative trustees" were following a 5 percent rule, and this is still invoked as a rough outer limit for investment in a single stock. ${ }^{56}$

Most of the modern cases on the duty to diversify involve so-called inception assets: the settlor has conveyed a large block of stock to the trust, often stock of the company he founded or worked for, and the issue is whether the trustee was imprudent in failing to sell it or sell it fast enough. ${ }^{7}$ Such cases usually turn on the express or implicit authorization of the settlor to retain the shares notwithstanding the otherwise applicable duty to diversify, ${ }^{58}$ and the scope of that duty is accordingly not in issue.

The duty to diversify was resisted for a time in the New York and Pennsylvania courts, beginning with a New York lower-court decision, In re Adriance's Estate. ${ }^{59}$ In 1928 the trustee had placed $\$ 100,000$ of a $\$ 260,000$ fund in mortgage bonds secured by a parcel of New York City real estate. The bonds fell in value in the depression. The beneficiaries argued that it was improper to place almost 40 percent of the fund in one investment. The court rejected the argument:

It is entirely true that many financial authorities advocate wide diversity of investment. It is equally true that others as strenuously affirm the contrary, and agree with the familiar admonition of the late Andrew Carnegie: "Put all your eggs in one basket and watch the basket." This "divergence of sentiment among the financial authorities would render a judicial decision in favor of either school of thought an ultrahazardous undertaking. ${ }^{60}$

55. Restatement of Trusts (Second) sec. 228 (1957). Neither the language of the section nor any of the accompanying text was changed between the first (1935) and second (1957) Restatements.

56. See the evidence extracted in Lichtenfels v. North Carolina Nat'l Bank, 268 N.C. 467, 151 S.E.2d 78, 79 (1966).

57. In re Mueller's Trust, 28 Wis. 2d 26, 135 N.W.2d 854 (1965); Steiner v. Hawaiian Trust Co., 47 Haw. 548, 393 P.2d 96 (1964); Lichtenfels v. North Carolina Nat'l Bank, 268 N.C. 467, 151 S.E.2d 78 (1966); Security Trust Co. v. Appleton, 303 Ky. 328, 197 S.W.2d 70 (1946).

58. E.g., Lichtenfels v. North Carolina Nat'l Bank, 268 N.C. 467, 151 S.E.2d 78 (1966), and Security Trust Co. v. Appleton, 303 Ky. 328, 197 S.W.2d 70 (1946).

59. 145 Misc. 345,260 N.Y.S. 173 (Sup. Ct. 1932).

60. Id. at 352,260 N.Y.S. at 181. 
Underdiversification may have been a sound entrepreneurial strategy for Andrew Carnegie, but the suggestion that it was appropriate for trust portfolios was not well received in many quarters. ${ }^{61}$ Nevertheless, the Supreme Court of Pennsylvania followed the Adriance case in a 1940 decision, ${ }^{62}$ which was immediately criticized. ${ }^{63}$

The New York and Pennsylvania decisions were premised on a belief that there was respectable authority in financial circles supporting a deliberate policy of not diversifying a trust's investments. That proposition was dubious at the time and is untenable today. Modern capitalmarket research has shown that underdiversification imposes on the portfolio an uncompensated risk that represents a deadweight loss to the risk-averse investor. The only issue on which some members of the investment community continue to resist the new learning concerns how far to diversify, not whether to do so. The New York Court of Appeals has admitted the relevance of diversification in dictum in the recent Spitzer case, and other leading state courts have strongly endorsed, and enforced, the duty to diversify. ${ }^{64}$ Congress has now imposed the duty to diversify investments on all pension trusts and other employee benefit plans covered by ERISA. ${ }^{65}$ If the issue were to arise today before the highest courts of New York or Pennsylvania, they would almost certainly abandon a position the underlying premise of which has been destroyed, and follow instead the Restatement rule.

Capital-market research has now supplied a scientific standard of what the Restatement calls "the risk of loss." The standard is the avoidance of diversifiable risk to the extent possible without incurring disproportionate costs, either transaction costs resulting from trading designed to create or maintain a diversified portfolio or opportunity costs resulting from forgoing unusual gains obtainable by concentrating on one or a few securities. ${ }^{6}$ As we have seen, such opportunity costs appear in

61. E.g., Note, Investments by Fiduciaries in Pennsylvania, 84 U. Pa. L. Rev. 640, 643 (1936). The Restatement of Trusts (First), which contained the duty to diversify that was carried forward in the Restatement of Trusts (Second) and is quoted above, was promulgated in 1935. See generally Note, Trust Fund Investment in New York: The Prudent Man Rule and Diversification of Investments, 47 N.Y.U.L. Rev. 527 (1972).

62. Saeger Estates, 340 Pa. 73, 77, 16 A.2d 19 (1940).

63. Note, 25 Minn. L. Rev. 806, 807 (1941).

64. In re Mueller's Trust, 28 Wis. 2 d 26, 135 N.W.2d 854 (1965); Steiner v. Hawaiian Trust Co., 47 Haw. 548, 393 P.2d 96 (1964); Mandel v. Cemetery Bd., 185 Cal. App. 2d 583, 8 Cal. Rptr. 342 (1960). See generally the authorities collected in Annot., 24 A.L.R.3d 730 (1969).

65. ERISA sec. 404(a)(1)(C).

66. Bines, supra note 17 , at $732-34,758,794-97$, is in general accord with our position. He writes: "Unless an investment manager has a strategy for controlling unsystematic risk to provide consistently better returns over those provided by the capital asset pricing model [i.e., those predicted by the theory of efficient markets] ..., an investment manager who fails to diversify introduces unsystematic risk into a portfolio for which his client receives no premium 
general to be unimportant in the setting of trust investment. It is true that a trustee who is obtaining an abnormally high return on stock of $\mathrm{X}$ Corporation will pay a high price if he sells off most of his holdings in $\mathrm{X}$ in order to increase the diversification of his portfolio. But given the tendency of efficient capital markets to equalize risk-adjusted returns across securities this situation will be rare-a point we think will be conceded even by those who refuse to accept the full implications of modern capital-market research. Therefore, transaction costs, considered in the next section, are the primary limitation on diversification.

It can be argued that since hardly any trust instruments contain express directions to the trustees to optimize diversification, the law would be outrunning the practice (and, inferentially, the wishes) of settlors if it adopted the scientific measure of diversification as the standard for the trustee's legal duty to diversify. However, most trust instruments say nothing at all about diversification or other details of the investment function. Particularly when they select banks or other institutional fiduciaries as trustees, settlors and their lawyer-draftsmen characteristically refrain from trying to dictate investment policy for future decades. They are confident that professional trustees will keep abreast of changing investment techniques and opportunities, and they believe that trust-investment law will not lag too far behind in measuring trustee performance by standards that will also keep abreast of changes in human knowledge.

\section{B. A Duty to Commingle}

Capital-market research indicates that a value-weighted portfolio of several hundred stocks may be necessary to eliminate nonnegligible diversifiable risk. Because of the high transaction costs involved in trading securities in small lots, a multimillion-dollar portfolio is required to eliminate such risk without incurring substantial transaction costs.

Many pension funds and some other trusts are large enough to achieve optimal diversification internally, but most trusts are too small.

and from which a client can expect no return." Id. at 758. The author also believes that "the law is bound to recognize the distinction between systematic and unsystematic risk as a benchmark for diversification." Id. at 796. "As more and more vehicles diversified over the market become open to investors lacking the means to diversify their own portfolios fully, investment managers should be expected to use such services to the extent that they do not conflict with defensible positive investment strategies." Id. However, he also says: "Plainly, the duty to diversify does not mean that an investment manager must achieve the total elimination of unsystematic risk in a portfolio." Id. at 794. Perhaps this means nothing more than that at șome point additional diversification may be unwarranted due to transaction costs. The logic of Bines's position, as of ours, is that the duty to diversify does call for the elimination of uncompensated, i.e., unsystematic, risk to the extent compatible with avoiding excessive transaction costs. 
Accordingly, we expect the law to move toward the imposition on trustees of a duty to pool small accounts into common trust funds large enough to eliminate all nonnegligible diversifiable risk. The duty to pool will first be applied to corporate trustees such as banks. There is ample authority for holding professional trustees to a higher standard of care in all aspects of trust administration than amateurs. ${ }^{67}$ Institutional trustees, by virtue of their volume of trust accounts and their favored position under the common trust fund statutes discussed below, have the necessary facilities to eliminate diversifiable risk through pooling of small accounts. Ultimately, however, the duty to pool small accounts should be extended to private trustees when appropriate mutual funds have been created for them. ${ }^{68}$

In a superficial sense, judicial recognition of a trustee's duty to pool small investment accounts reverses the conventional rule against commingling trust funds. It is important, therefore, to understand the purpose of that rule, to note the exceptions that have developed in this century, and to recognize how strongly the policy behind those exceptions supports the duty to pool small accounts advocated here.

In conventional trust law, the trustee is said to be under a duty to keep trust property separate from the trustee's own property "and so far as it is reasonable that he should do so, to keep it separate from other property not subject to the trust," 69 including other trust accounts. The principal reason for requiring the trustee to earmark trust property is that "[w] ere [the trustee] permitted to do otherwise it would place before him the constant temptation to make the trust fund a dumping ground for his own unsatisfactory ventures."70 Similarly, if the trustee were not required to separate his trust accounts, he could play favorites among them in allocating winning and losing investments.

But an absolute ban on commingling trust funds was found to be too strict because it barred small trusts from desirable forms of investment. The first major form of commingled trust investment to develop was the mortgage participation. The trustee would make a large firstmortgage loan, allocating portions-represented by so-called participation certificates issued by the trustee-among several trust accounts.

67. Uniform Probate Code sec. 7-302; Restatement of Trusts (Second) sec. 174 (1957); 2 Austin W. Scott, The Law of Trusts sec. 174.1, at 1412-15 (3d ed. 1967) [hereinafter cited as Scott, Trusts]. For strong recent authority see In re Estate of Beach, 41 Cal. App. 3d 418, 116 Cal. Rptr. 418 (1974).

68. At this writing only Batterymarch offers a no-load market fund to private trustees; it requires a minimum investment of $\$ 1$ million. Vanguard's First Index fund has no minimum, but has a sales charge, discussed in text at note 92 infra.

69. Restatement of Trusts (Second) sec. 179 (1957).

70. Cornet v. Cornet, 269 Mo. 298, 322, 190 S.W. 333 (1916). 
"This device was adopted and has grown in favor," explained the Massachusetts Supreme Judicial Court, "because of the difficulty which corporate fiduciaries have experienced in obtaining first mortgages upon real estate in the Commonwealth in amounts small enough to be held in smaller trusts and to provide the diversification desired in larger trusts." 11 Moreover, it was found that alternative safeguards served the purpose of the former rule nearly as well: the trustee was required promptly to earmark the several accounts on its own books and to issue participation certificates in the name of the accounts, and these steps were subject to audit by bank regulators. ${ }^{72}$

Experience with mortgage participations undercut the rationale for the rule against commingling and thereby increased the pressure to permit pooling of other investments. The Uniform Common Trust Fund Act was promulgated in 1938, and every American state has now enacted it or a variant. ${ }^{73}$ The Uniform Act authorizes "[a] ny bank or trust company qualified to act as a fiduciary in this state" to establish commingled funds for trust investment. ${ }^{74}$ The purpose, in the words of its draftsmen, is to permit trustees "to diversify the investments of ... several trusts and thus spread the risk of loss . ..."75

Common trust funds came into existence in order to facilitate the duty to diversify. Accordingly, it would involve no violation of fundamental principle to insist that trustees are under a duty to utilize common funds when necessary to achieve the degree of diversification now understood to be desirable.

We have thus far been speaking of the duty to diversify and the concomitant duty to pool small accounts in the context of common stocks, but these principles logically extend to trust investments in bonds as well. Bank common trust funds having bond components or even wholly limited to bonds are by no means novel, although many banks that accept trust business do not offer bond common trust funds or have not used them systematically.

An example is a case currently being litigated in lowa. Of necessity we base our discussion on the facts as pleaded, not as they may ultimately appear. A bank trust department managing a widow's $\$ 110,500$ trust fund decided in 1973 to invest $\$ 25,000$ in corporate bonds. ${ }^{76}$ Because

71. Springfield Safe Deposit \& Trust Co. v. First Unitarian Soc'y, 293 Mass. 480, 200 N.E. 541 (1936).

72. 2 \& 3 Scott, Trusts, supra note 67 , secs. $179.4,227.9$.

73. See $3 i d$. sec. 227.9 , at 1830 n.26.

74. 7 U.L.A. 40 (1970).

75. "Commissioners' Prefatory Note," $i d$. at 37-38.

76. The rest of the portfolio: $\$ 56,000$ in corporate stocks, $\$ 8,800$ in government bonds, $\$ 8,700$ in commercial paper, $\$ 11,000$ in a land contract. 
the commission rates and spreads on bonds make it mildly advantageous to deal in $\$ 25,000$ lots, the bank placed the widow's $\$ 25,000$ entirely in the bonds of a single issuer. The issuer in this case was the Franklin New York Corporation, parent company of the Long Island bank that went bankrupt in 1974, and the bonds are now in default.

The trustee's conduct appears to be in breach of the duty to diversify. The $\$ 25,000$ investment in Franklin New York bonds was rightful in type but wrongful in amount. A trustee cannot be expected to discern in advance of the market that a seemingly sound issuer has surreptitiously compromised itself. But precisely because the trustee does not have superior foresight, he should diversify the investments of each trust so as to minimize the risk of the unforeseeable. The trustee should not have subjected the widow's $\$ 110,000$ trust fund to the uncompensated risk of losing nearly a quarter of the corpus. If he felt obliged to realize the economies of bond trading in $\$ 25,000$ multiples, he had a correlative duty to pool the widow's $\$ 25,000$ with other trust funds invested in bonds in order to discharge his duty "to distribute the risk of loss by a reasonable diversification of investments ...."77

\section{The Duty of Nondelegation}

A recent circular issued by the Comptroller of the Currency requires that in discussing the duty to pool we recur to a subject discussed at length in our former article: the trustee's purported duty of nondelegation of investment powers. The nondelegation doctrine does not come into play when a trustee such as a bank combines its trust accounts in an in-house common fund under its own continuing management. But pooling does result in delegation when the trustee uses a multibank fund of the type authorized in New York ${ }^{78}$ or when a private trustee uses an investment company (mutual fund). Someone other than the trustee, that is, a delegate, acquires the trustee's discretion to make investment decisions.

In our former article, we described the several formulations of the nondelegation rule that have appeared in the cases and noted the disfavor in which the rule is held by modern authorities. ${ }^{79}$ We emphasized how completely trust law abandoned its original distaste for mutual funds once the point was grasped that an investment in ordinary company shares involves even greater delegation of discretion to company managers than was permitted to mutual fund managers under the Invest-

77. Restatement of Trusts (Second) sec. 228 (1957).

78. See 3 Scott, Trusts, supra note 67 , sec. 227.9 , at 1833 n.28.

79. Market Funds I, supra note 1, at 18-24. 
ment Company Act of 1940. We said that since 1947, when an Ohio court approved a trust investment in mutual fund shares, not one contrary judicial decision had been reported. And we pointed out that in nearly half the states there is legislation authorizing trust investment in mutual fund shares, while no state has a contrary statute.

On December 23, 1975, the Comptroller of the Currency issued a trust-banking circular which stated: "It has been and remains the position of this Office that the investment of trust assets in shares of mutual funds constitutes an improper delegation of the trustee's investment authority under the common law." 80 No reason or authority was advanced in support of this pronouncement.

The subject of the circular was a major new product of the mutual fund industry, the "money market funds" that invest in short-term government, bank, and commercial paper. These funds pool small cash balances for investment in instruments that can yield higher rates than ordinary savings accounts. They credit interest daily and permit immediate redemption, hence replicating all the salient features of savings accounts (except government insurance). The circular declared: "Various 'money market funds' are currently being offered for the short term investment of small amounts of trust cash. These funds are mutual funds and as such are subject to the above stated" view of the nondelegation rule.

Having so declared, the Comptroller's circular then conceded by way of exception most of what it had forbidden. The improper delegation involved in trust investments in mutual fund shares "may be authorized ... only if there exists (A) specific authority in state statutes or decisions; (B) specific authority in the appropriate governing instrument for a given account; or (C) binding consents from all beneficiaries." Since most of the major trust banking states have statutes authorizing trust investment in mutual funds, banks in those states have been counseled to disregard the circular. ${ }^{81}$

80. Trust Banking Circular No. 4, "Subject: Investment of Trust Assets in Mutual Funds," a four-paragraph circular letter issued over the signature of Dean E. Miller, deputy comptroller for trust operations, and addressed to "Regional Administrators, President of Banks with Trust Powers (Attention: Senior Trust Officers) and Trust Examiners."

According to a report published as this article was in press, the Comptroller issued a ruling on September 29, 1976, largely recanting the December 23,1975, ruling by remiting the question entirely to state law. Paul R. Merrion, Banks Can Use Money Market Funds If They Decide It's Prudent, Pensions \& Investments, Oct. 11, 1976, at 1.

81. "At this point most trust officers appear to be relying upon option [i.e., subsection] ' $A$ ' of the Comptroller's statement to implement the use of money market funds." Bruce R. Bent, Sorting Out the Money Market Funds, 115 Trusts \& Estates 408, 409 (1976).

On the prevalence of pension-trust and pension-fund investment in mutual funds in general, see Investment Company Institute, 1975 Mutual Fund Fact Book 48-51 (1975). Cf. Michael Clowes, Mutual Fund Managers Attracting Big Bucks from Small Pension Plans, Pensions \& Investments, Apr. 12, 1976, at 20. 
The Comptroller's circular purports to state as "the common law" a rule that has been rejected by decision or statute in every common law jurisdiction that has considered the point in the last three decades, and it offers no justification for the deviant position taken. The position of the Comptroller is all the more remarkable because it contradicts (without mentioning) recent congressional and administrative authority for pension-trust investment in mutual fund shares. Section $401(\mathrm{~b})(1)$ of ERISA expressly permits pension funds to invest in mutual funds registered under the Investment Company Act of 1940. The Labor Department's administrator of pension and welfare benefit programs has issued an opinion letter in which he noted that "the legislative history of" ERISA shows that Congress contemplated that pension funds might invest "exclusively in shares of a mutual fund," and that accordingly "the underlying assets of such mutual fund should be taken into consideration" in determining whether the diversification requirement of section $404(a)(1)(C)$ of ERISA is satisfied. ${ }^{82}$

We conclude, as in our previous article, that whatever force the trustee's duty of nondelegation may have elsewhere in trust law, it has no bearing on trust investment in mutual fund shares.

\section{The Deviation Doctrine}

The question may arise how the law should deal with trusts in which the settlor has directed the trustee to follow an investment policy that results in significant underdiversification.

The general rule of trust-investment law is that the settlor may impose on the trust whatever investment policy he sees fit. ${ }^{83}$ There are some rudimentary limits on the settlor's discretion, not well developed in the case law, ${ }^{84}$ but in the main he has the same freedom respecting investment that he has in designating trust beneficiaries. The law seems to have reached this result for two reasons. First, it respects the settlor's property rights. It allows him to extend to his trustee the same power that he himself had to manage his property in an eccentric fashion. Second, the settlor is presumed to have special wisdom respecting the needs of his beneficiaries. When he insists on the retention of the family farm or the family firm, the settlor is supposedly acting in the best interest of beneficiaries whom he knows well, and that rationale has

82. Opinion letter of November 4, 1975, issued by James D. Hutchinson, administrator of pension and welfare programs, U.S. Department of Labor, citing Joint Explanatory Statement of the Committee of Conference, H.R. Rep. No. 93-1280, 93d Cong., 2d Sess. 305 (1974) (emphasis added).

83. See generally 2 Scott, Trusts, supra note 67 , sec. 164 , at 1254 .

84. See, e.g., Colonial Trust Co. v. Brown, 105 Conn. 261, 135 A. 555 (1926). 
been allowed to carry over to the family block of IBM common stock. The settlor's discretion in setting investment policy extends to matters of diversification. ${ }^{85}$ Presumably, a settlor could recite in the trust instrument that he wants the beneficiaries to experience the thrill of uncompensated risk and that accordingly the entire fund shall be invested in Lockheed stock. When it is clear that the settlor understood the danger of underdiversification, the law will let him inflict it upon the trust. Naturally, few settlors are eccentric enough to explore the borderlands of their power to dictate uneconomic investment policy.

It is more common, although still relatively rare, for the settlor to prescribe an investment policy (usually the retention of inception assets) in which underdiversification is not the object but an incidental consequence. Or there may be a restriction forbidding the trustee to pool the trust assets in a common fund; typically, such restrictions appear in older instruments that date from a time when, because the common trust fund was relatively untried or not yet confirmed by statute, careful draftsmen chose to exclude it in order to spare their trusts the hazard of possible litigation. ${ }^{86}$

While restrictions resulting in incidental underdiversification are presumptively valid, trust law has developed a device to relieve against restrictions that prove inadvisable in the light of changed circumstances. The so-called deviation doctrine permits the trustee to apply to the court to be excused from complying with a condition that has become impractical or inadvisable for reasons not foreseen by the settlor. ${ }^{87}$ The leading case of In re Pulitzer 8 illustrates the operation of the rule. Joseph Pulitzer created a trust for his survivors. The trust corpus included his interest in the New York World newspaper, which he directed the trustees not to sell. Some years later the paper fell upon hard times and began running persistent deficits. On application of the trustees the court approved the sale of the paper. It said that Pulitzer's dominant intent must have been to benefit the beneficiaries of his trust.

85. The Restatement formulation of the duty to diversify, in text at note 50 supra, is prefaced with the proviso "Except as otherwise provided by the terms of the trust ...."

86. See, e.g., In re Griffith, 66 N.Y.S.2d 72 (Sup. Ct., Special Term 1946), involving a 1911 instrument containing both types of direction. The settlor required the trustee to retain the entire fund in the inception assets, 4 percent first mortgage bonds of the West Shore Railroad Company due in the year 2315, and to hold the fund "separate and apart from all other property held by it...."Id. at 73. The trustee sought enlarged investment powers under the New York statutory version of the common law deviation doctrine. The court denied the application, reasoning that since the bonds were still selling at $841 / 4$ (compared with $971 / 2$ when transferred to the trust), there was insufficient change of circumstances to justify invoking the doctrine.

87. Restatement of Trusts (Second) sec. 167 (1957).

88. 139 Misc. 575,249 N.Y.S. 87 (Surr. 1931). 
Continued operation of the newspaper was a subsidiary direction, and in a conflict between the two the settlor's dominant intent should prevail. In another well-known case, In re $\mathrm{Mayo}^{89}$ the Minnesota Supreme Court used the deviation doctrine to eliminate a restriction forbidding the trustee to invest in common stock. The court cited changes in the rate of inflation and the improved regulation of the securities markets as factors unforeseen by the settlor.

The lessons of postwar capital-market research invite the application of the deviation doctrine to trusts whose investment restrictions would otherwise preclude optimum diversification. Only in recent years have the substantial benefits of optimum diversification, and the investment practices that must be followed in order to create a properly diversified portfolio, become recognized. These discoveries were unknown and unforeseeable to trust settlors until recently. And we remind trustees that the deviation doctrine as codified in the Restatement of Trusts (Second) not only authorizes them to seek relief from outmoded trust terms in cases of changed circumstances but places them under a duty to do so. ${ }^{90}$

\section{MARKET FUNDS, BANKS, AND THE SMALL INVESTOR}

One of the curiosities of the initial development of market funds in the mid-1970s is that they were not offered to the general public, that is, to small investors who lack the resources needed to create their own. The three financial intermediaries that pioneered $^{91}$ market funds-American National Bank of Chicago, Batterymarch Financial Management Corporation, and Wells Fargo Bank-all limit participation to trust or institutional accounts, in practice mostly pension funds. The banks are forbidden by federal regulation to offer investment-company services unconnected with their trust services. Batterymarch was willing to design and manage a market fund for small investors but was unable to attract a retailer such as an existing mutual fund organization or

89. 259 Minn. 91, 105 N.W.2d 900 (1960). For other cases both allowing and refusing to allow deviation from investment restrictions, see 2 Scott, Trusts, supra note 67, sec. 167, at 1271-76.

90. Restatement of Trusts (Second) sec. 167(3) (1957).

91. Wells Fargo created the first market-matching vehicles; $c f$. Fischer Black \& Myron Scholes, From Theory to a New Financial Product, 29 J. Finance 399 (1974). The three organizations named in the text are now being joined by competitors. Bankers Trust, one of the nation's largest pension-fund managers, is setting up a market fund for employee-benefit accounts. See Bankers Trust Enters Index Fund Competition, Pensions \& Investments, Sept. 13, 1976, at 1. Manufacturers' National Bank of Detroit is also instituting a commingled equity market fund. See Ford Motor Turns over Index Fund to Bank, Pensions \& Investments, Sept. 13,1976 , at 2 . 
brokerage house to merchandise it and administer the paper work involved in small accounts.

\section{A. Mutual Funds}

Finally, in July 1976 the Vanguard Group of Investment Companies, a major mutual fund organization that operates a dozen managed funds of varying character, launched First Index Investment Trust. First Index is an open-end investment trust, that is, a mutual fund that adjusts to changes in shareholder investment by issuing or redeeming shares. It is the first mutual fund designed to match the market, in this instance to track the S\&P 500 .

First Index is a load fund; the investor is charged a 6 percent sales fee, ${ }^{92}$ which is retained by the broker from whom he buys the shares. Load funds are to be distinguished as a genre from no-load funds, which also exist in considerable number. A no-load fund sells its shares directly to the investor, and there is no saleman's commission to be deducted from the investor's capital.

The initial public offering of First Index shares (concluded in August 1976) raised about $\$ 12$ million, enough to create a marketmatching portfolio but well short of the $\$ 30$ million that the sponsors had hoped to raise. (A continuous public offering of new shares, also subject to the load charge, will begin shortly when the fund is fully operational.)

One reason that First Index received only a lukewarm reception for its initial offering is that some investors were unwilling to pay the load charge. Investors who are sophisticated enough to know about the theory of efficient markets and to appreciate the hopelessness of attempting to outperform the market are sophisticated enough to prefer no-load mutual funds. There is every reason to think, therefore, that most of the small investors who have been wanting to invest in a market fund are still waiting for the mutual fund industry to provide a no-load vehicle. ${ }^{93}$

92. In the initial public offering, shares were priced at $\$ 15.00$. The sales charge (underwriting commission) was $\$ 0.85$ per share -6.01 percent of the remaining $\$ 14.15$ received for investment by the trust. On investments in excess of $\$ 50,000$, the schedule of commissions declined as follows (in round numbers): up to $\$ 100,000,5$ percent; up to $\$ 500,000,3$ percent; up to $\$ 1$ million, 2 percent; above $\$ 1$ million, 1 percent. First Index Investment Trust, Preliminary Prospectus, July 30, 1976, at 1,14 . These figures remained unaltered in the final prospectus. First Index Investment Trust, Prospectus, Aug. 23, 1976, at 1, 14.

93. See, e.g., the column published by Paul Samuelson during the First Index initial offering, commending the advent of a market fund for small investors but warning that "frontend loads are hard to justify...." Samuelson, Index-Fund Investing, Newsweek, Aug. 16, 1976, at 66.

In a memorandum commenting upon an earlier draft of this article, John Bogle of Vanguard 
The Vanguard Group, aware of course that many investors would balk at the load charge, considered constructing First Index as a no-load fund. (Because Vanguard has no brokerage arm, all of the load proceeds went to compensate other firms for their sales effort.) The factors that led Vanguard to organize First Index as a load fund are instructive for the future of market-fund investing.

When a no-load fund is launched (regardless of its investment strategy), it can and typically does start with a comparatively small initial capital. It hopes to grow as word of its strategy or performance spreads, usually aided by advertising and promotion in the financial and general press. Its selling expenses, mostly for advertising, are charged off against the fund's income indirectly through the management fee of the fund sponsor.

A market fund, however, cannot start small and grow. To assemble a portfolio of several hundred stocks at acceptable levels of transaction cost requires a multimillion-dollar initial investment. In the case of First Index, the sponsors felt that they could not raise such a sum quickly enough without engaging a sales force. They did explore the alternative of raising the initial investment for a no-load fund from one or more institutional investors, but such "seed money" was not forthcoming. The institutions already have market funds available to them, and in some cases they have enough assets to create their own. Vanguard also was troubled by a legal obstacle in attempting to raise the seed money from a few large institutions: if five or fewer shareholders own 50 percent or more of the shares during the last half of a taxable year, the Internal Revenue Code treats the fund as a personal holding company subject to onerous surcharge..$^{94}$

put two principal points in defense of the First Index load charge. First, when amortized over a long enough holding period, load charges can compare favorably with the steady drain of sales costs charged as expenses in a no-load fund. Second, as long as a no-load fund is unavailable, the First Index "sales charge was highly competitive with the cost of the most modest possible diversification on an 'individual stock' basis; i.e., round trip stock exchange commissions for an individual diversifying in just 10 stocks would be $7.8 \%$ at the $\$ 5,000$ level, $6.0 \%$ at the $\$ 10,000$ level and $4.2 \%$ at the $\$ 25,000$ level . . ." John Bogle, Memorandum of Sept. 15, 1976, at 2 (copy on file with A.B.F. Res. J.).

Vanguard believes that investor resistance to the load charge was less important than other factors in holding down the initial public subscription to First Index. It thinks that any mutual fund must overcome a stigma, evidenced in the high net redemption rates of recent times, which it attributes to the market crash of the 1970s (and which may also reflect the sales abuses of the 1950 s and 1960s). "Despite our efforts to differentiate First Index, it was perceived as a mutual fund-and it is difficult to sell mutual funds these days." Id. at 1. It also emphasizes the difficulty of explaining to the uninitiated a counterintuitive investment strategy and the awkwardness of having to rely on brokers (whose basic source of income is clients' stock picking) to explain the futility of stock picking to those clients.

Nevertheless, the point remains that a no-load fund has yet to be tried. No one knows how large or small the latent demand for a no-load market fund really is.

94. I.R.C. secs. 541-42. 
The ability of First Index to raise $\$ 12$ million despite investor resistance to its load charge suggests that there may be significant demand for a no-load market fund. Yet potential sponsors have been reluctant to mount the intensive advertising campaign that might be needed to launch a no-load fund without institutional seed money. The firm that considers incurring the advertising outlays to educate the public about market-fund investing must fear that it will attract not only investors, but competitors who will reap the innovator's harvest. The idea of market matching. cannot be patented or otherwise appropriated. And implementing the concept is quite straightforward. ${ }^{95}$ Any investment company could take a "free ride" on the pioneer's advertisingand offer investors an even cheaper market fund because it would not be burdened with advertising costs comparable to the pioneer's.

Furthermore, the existing retail mutual fund organizations that could most easily launch no-load funds have generally been hostile to the idea, fearing that it would be inconsistent for them to offer market-matching funds. Their existing funds have been sold to the public on the representation that their managers possessed superior skills of stock picking. It would undercut that claim for the same organizations to be offering market-matching vehicles premised on the recognition that their investment managers do not in fact outperform the market. The same tension was present in the First Index underwriting and may help explain the lackluster performance of the major brokerage firms in the syndicate that handled the initial public offering of that fund.

Finally, investment managers know that they will make much less profit running market funds than conventional managed funds. It is hard to charge much of a management fee for matching an index. Indeed, First Index pays no direct management fee to its sponsor and expects its expenses to be so $\operatorname{low}^{96}$ as to make the fund essentially a nonprofit undertaking of the Vanguard Group.

\section{B. Banks}

Were it not for government regulation, the banks-the main in-

95. Of course, there are professional skills involved in constructing a market-matching vehicle, monitoring its performance, and trading in response to fund inflows or redemptions. See, e.g., Harvey D. Shapiro, How Do You Really Run One of Those Index Funds? 10 Institutional Investor 24 (1976). But by comparison with old-fashioned stock picking and portfolio turnover, market-fund managers have much less to do and to charge for, and investors expect the savings to be passed on.

96. The preliminary prospectus of July 30 , supra note 92 , at 1,3 , projected an annual operating expense ratio of two-tenths of 1 percent for a $\$ 30$-million fund. The final prospectus of August 23, supra note 92, at 1,3, issued after preliminary sales activities, assumed a $\$ 17-$ million sale and increased the annual expense ratio to three-tenths of 1 percent. 
novators of market funds-would have offered them long ago to their nontrust customers. Given the reluctance of the mutual fund industry to offer no-load market funds for ordinary investors at reasonable cost, we question whether it is desirable regulatory policy to forbid the banks to meet this demand.

In the 1971 Camp case 7 the United States Supreme Court held that the Glass-Steagall Act of $1933,,^{98}$ the source of the prohibition against national banks' offering investment banking services, forbade banks to operate conventionally managed mutual funds. The Court emphasized that it was simply construing the 40-year-old language of the statute, which reflected a congressional "determination that policies of competition, convenience, or expertise which might otherwise support the entry of commercial banks into the investment banking business were outweighed by the 'hazards' and 'financial dangers' that arise when commercial banks engage in the activities proscribed by the Act." 99

The Court purported to find in the legislative history a number of "hazards that Congress had in mind ...." 00

1. A bank might impair its capital by investing "its own assets in frozen or otherwise imprudent stock or security investments."

2. If the investment banking activities should "fare badly, public confidence in the bank might be impaired."

3. The bank might be tempted "to shore up" its investment banking affiliate "through unsound loans ...."

4. The bank might distort its commercial banking activities in favor of companies in whose securities its investment banking side was interested. "Congress feared that banks might even go so far as to make unsound loans to such companies."

5. Banks would suffer a "loss of customer good will" when depositors and other commercial banking customers made losing investments through the bank's investment banking affiliate.

6. Banks might encourage speculative fever by making commercial loans to their customers for the purchase of securities from the investment banking affiliate.

97. Investment Co. Inst. v. Camp, 401 U.S. 617 (1971).

98. 48 Stat. 162, codified in Title 12, U.S.C. The Court concluded that bank-operated mutual funds violated sec. 16 of Glass-Steagall, now 12 U.S.C. sec. 24(7) (1970), prohibiting a national bank from purchasing the shares of other companies "for its own account," and sec. 21 of Glass-Steagall, 12 U.S.C. sec. 378(a) (1970), forbidding a national bank to underwrite any issue of securities.

99. 401 U.S. at 630.

100. Id. The eight points numbered in text are listed in the order contained in the opinion, id. at $630-33$. 
7. There would be a "plain conflict of interest" in that banks could no longer fulfill their "obligation ... to render disinterested investment advice."

8. A bank might "unload excessive holdings" from investment company activities onto the trust department.

The Court conceded that these were "subtle hazards ...."101 To observers in the 1970s, most of these "hazards" will appear quite farfetched. A bank can as easily impair its capital by making bad commercial loans as by buying bad securities. Public confidence can as easily be impaired when commercial loans sour as when investments go bad. Indeed, the whole concern with "public confidence" and "loss of customer good will" had to do with preventing runs on banks, a problem now largely eliminated by a combination of Federal Reserve Board policy and federal deposit insurance. Customers appear more likely to borrow improvidently for automobiles and home improvements than for securities, yet banks are not suspected of "conflict of interest" when they solicit consumer loan business.

The Supreme Court decided in the Camp case that these "same hazards are clearly present when a bank undertakes to operate an investment fund."102 However, the Court reached this conclusion before the advent of market funds. Although some of the supposed hazards would be present no matter what form of investment fund a bank were to offer, others are peculiar to old-fashioned stock-picking funds and would not arise in the case of a market fund. For example, only when a bank can exercise discretion to decide whether to include a particular company's shares in its fund might it acquire some power to induce that company to accept relatively unfavorable credit terms from its commercial banking department in exchange for supporting the company's common shares by including them in its investment fund. A market fund, by contrast, would buy or not buy the shares in accordance with their presence and weight in the market index; the bank would lack discretion, so the opportunity to abuse it would also disappear. The Court feared that " $[t]$ he bank might exploit its confidential relationship with its commercial and industrial creditors for the benefit of the fund," 103 but this, too, presupposes stock picking; a market fund has no use for confidential information. The concern with trust-department purchases likewise assumes stock-picking discretion in the fund. The Court also pointed out that " [i] mprudent or unsuccessful 
management of the bank's investment fund could bring about a perhaps unjustified loss of public confidence in the bank itself,"1 04 but because a market fund is unmanaged, it avoids this danger. Finally, the supposed conflict with the bank's obligation to render disinterested investment advice is greatly diminished when the bank is not trying to justify particular stock-picking recommendations.

The Glass-Steagall Act of 1933 predates the Investment Company Act of 1940, which gave birth to the modern mutual fund industry. Glass-Steagall was designed to keep banks from engaging in conventional investment-banking activities such as underwriting the securities of particular companies. Congress did not have mutual fund activities in mind, and it was not until the Camp case that the Supreme Court held that they fell within the scope of the Glass-Steagall prohibition. In reaching that result the Court assumed that "the bank's funds would be in direct competition with mutual funds that, from the point of view of the investor, offered an investment opportunity comparable to that offered by the bank."105 As we have seen, however, the mutual fund industry has thus far failed to come forward with a no-load market fund.

From the perspective of the mid-1970s, much of the supposed rationale for the Glass-Steagall Act is stale, imaginary, and unconvincing. Because market funds avoid many of the dangers that worried the Congress during the Great Depression, we think that market funds provide an especially attractive opportunity for Congress to amend Glass-Steagall to permit experimentation with bank-operated investment funds.

The small investor is at a disadvantage in the traditional game of stock picking, because his information costs are disproportionately large. Thus far, the small investor who has been unwilling to pay mutual fund load charges and/or management fees has been forced into stock picking with its consequent expense and underdiversification. Often his real desire is simply to direct some of his personal savings into equity investment. One indication of the willingness of small investors to accept efficient-market security pricing in return for lowered transaction costs is the rapid spread in recent years of automatic dividend reinvestment plans. Investment companies have long had such plans, which are now spreading to industrial companies and especially to the capital-hungry utility companies. The investor who owns shares in a company that has such a plan commits himself well in advance to have his cash dividends applied to the purchase of additional shares of the company at whatever 
the market price on the dividend date. The attraction to the investor is the elimination (or in some cases the reduction) of brokerage costs, which are otherwise quite steep for small investments.

Especially at a time of mounting concern with the level of capital formation in America, it is unwise to place artificial impediments in the path of those individuals who wish to make equity investments in the attractive format of the market fund. Banks seem especially suited to provide this format: as a supplement to the automatic monthly savings plans that they now operate for savings account customers, they could readily offer the option of automatic investment in a market fund.

Moreover, banks at present are permitted to solicit standing orders from individual customers for specific securities and to combine the orders and execute them as agent. ${ }^{106}$ Some banks operate plans by which a customer authorizes the bank to debit his account a certain amount per month for the purchase of shares (including fractional interests in shares) in one or more stocks designated by the customer from a bank-supplied list of 25 or so. (The list is kept small, and in practice is limited to the most widely held companies, in order to generate reasonable monthly volume in each stock.) In the operation of these plans, none of the supposed hazards that-according to the Camp case-motivated the Glass-Steagall Act has materialized. Banks are already permitted to offer their customers a monthly investing plan in AT\&T, IBM, and GM; we see no reason in logic or in policy why they should not also be able to offer S\&P 500 .

By comparison with mutual funds, banks would have natural advantages as suppliers of no-load market funds for small investors, because the funds would complement existing bank services. Commercial banks already have a large retailing capacity in place serving a huge number of potential investors, from whom their market funds could be expected to generate sufficient volume to operate at low expense ratios. The existing relationship between banks and potential investors would facilitate acceptance of market-fund investing and drastically reduce sales costs. Nor are banks at any disadvantage in creating and operating market funds, as is demonstrated by their pioneering role in creating the first market funds for their trust accounts. The potential economies

106. See generally Note, The Legality of Bank-sponsored Investment Services, 84 Yale L.J. 1477 (1975). In the application form that it uses to enroll customers in its Monthly Investment Service, the First National Bank of Chicago explains how the stocks were selected: "The stocks listed are the 25 largest, in terms of the market value of shares outstanding, in Standard \& Poor's Industrial Index and were chosen, without subjective evaluation by the Bank, solely upon share market value rank in that Index." According to Herbert V. Prochnow, Jr., counsel, the bank "presently has about $1 \%$ of its checking account customers signed up for the monthly investment plan." Letter to the authors (Aug. 10, 1976). 
from using existing bank offices to service the equity-investing needs of the public are apparent. Banks are more conveniently located to most individuals than are stockbrokers' offices, and they have an ongoing financial relationship with the customer/investor. The conflict-of-interest dangers that have been relied upon to justify the separation of the banking and securities businesses, despite the manifest cost advantages of combining them, are, as we have seen, greatly attenuated when bank participation in the securities business is limited to the sale of shares in market funds. 
HeinOnline -- 1977 Am. B. Found. Res. J. 441977 